\title{
Multicultural Citizenship and the Status of 'Others' in the Post 1991 Ethiopia: A Study on Membership and Self-Governing Status of Amhara People in Benishangul-Gumuz Regional State
}

\author{
K.T. Muluye \\ University of Gondar \\ P.O. Box 196, Gondar, Ethiopia
}

\begin{abstract}
Following the regime change in 1991, the Ethiopian government sought to institutionalize inclusive multicultural citizenship in the country. Membership status and selfgoverning rights are crucial entitlements in the multiculturalists' notion of citizenship. Though citizenship is considered to be part of domestic affairs of a state, it is also influenced by the policies of sub-state political units. Hence, this paper examines the membership and self-governing status of Amhara and analyzes how the citizenship status is affected at sub-state units, with a focus on Benishangul Gumuz Regional State. Concurrent embedded mixed approach was employed and data were collected through interviews and document analysis. Interview data were obtained from 29 respondents, chosen by means of an intensity sampling method. Quantitative data were also acquired from Ethiopian Central Statistical Agency. The data were analyzed qualitatively with some quantitative backup. Though Amhara People of BGRS have the legal status of Ethiopian citizenship, BGRS has failed to fully integrate these people to the mainstream political community. Particularly, the exclusionary politics of recognition (as only selected nationalities receive the so-called ownership of the region) and the prohibition of Amhara from exercising selfgovernment rights (this right is exclusively given to the 'owner' nationalities by the regional constitution) demonstrate the hierarchy of citizenship, where Amhara people are treated as secondclass citizens in BGRS, which is contradictory to the notion of multicultural citizenship.
\end{abstract}

Keywords: Amhara, Ethnic Federalism, Ethiopia, Multiculturalism, Multicultural Citizenship, Politics of identity

\section{Introduction}

Citizenship, which is bound by reciprocal rights and duties, is seen as a legal relationship between individuals/groups and the state [1]. Today, however, it is almost universally accepted that viewing citizenship as a mere legal status is erroneous [2]. Modern citizenship is understood in terms of four interconnected di- 
mensions: membership, legal status, rights and participation [2]. Membership refers to an inclusion in a particular cultural and political community either at the state or sub-state levels [2]. It is one of the crucial components in establishing citizenship since the distribution of rights and duties is determined by the distinctions between 'insiders' and 'outsiders' in a community [2]. As a result, the politics of inclusion/exclusion to/from a particular political community significantly influences the citizenship status.

The second constituent of citizenship is the legal status. This is a contractual relation between an individual and the political community. It is granted by applying the principle of jus solis (place of birth), jus sanguinis (citizenship of parent/s) or 'naturalization' depending on the specific citizenship law of a particular state [2]. Although one would expect the legality of citizenship to be the determinant factor, the mere legal status in itself is not sufficient to enjoy full citizenship status [1]. The third element of citizenship is participation. When individuals are legally recognized as citizens, it is expected for them to be charged with duties. Citizenship in the form of participation is explained in terms discharging responsibilities, such as obligatory taxes or military services [2].

The final component of citizenship is the rights. As has been stated before, individuals who are legally recognized as citizens of a particular state are entitled with privileges named rights [3]. Citizenship and the Social Class by T.H. Marshal (1950) is considered to be a seminal work on the typology and lists of citizens' rights. However, given the ever expanding definitions of civil rights, the catalogue has been supplemented with news lists, for example, self-governing rights [3]. Undeniably, this right is central in the multiculturalists' notion of citizenship [2]. Both Kymlicka [4] and Young [5], well-known advocates of multicultural citizenship, believe self-government to be an important tool that protects ethnic 'minorities' from marginalization and oppression. Of all the four dimensions of citizenship, this paper is focused on membership and self-governing status, which will be analyzed in order to reveal Amhara's standing in the region.

In talking about citizenship, it is also important to note that "citizenship is not only a matter of state but also of sub-state, supra-state, or non-state political communities" [6]. As a result, it appears practical to "employ the concept of citizenship to analyze sub-state policies and programs that affect citizens in different ways' [6]. Mainly in federal states, such as Ethiopia, where entitlements and privileges are determined by the ethno-linguistic identities, analyzing the sub-state policies and legal frameworks that regulate the distribution of prerogatives is imperative. In order to establish home territories at sub-state levels and label inhabitants as 'owners' and 'nonowners' (as required by the regional constitution), the Ethiopian authorities have created two levels of citizenship [7]. Hence, this paper seeks to examine the way the 'others' ${ }^{1}$ are treated at the sub-state levels, with a focus on Amhara in BGRS.

${ }^{1}$ In this paper, the terms 'others' or 'new minorities' are used to refer to ethnic groups residing outside 'their ethnically determined' territorial unit. In terms of population size, the 'others' can outnumber the 'owners' or titular nationalities, as is the case with Amhara in BGRS and Harari [16]. 
Although an individual may be a legal citizen, they may feel that they are not enjoying citizenship rights to the full extent. This inequality is created by de jure and de facto exclusions at the state or sub-state levels, resulting in a hierarchy of citizenship. Hierarchy of citizenship (first class, second class, and underclass) emerges when a certain society domain displays a higher level of integration into the socio-political community (as compared to others) and articulates its demands more effectively than others. The rest, who have a different religion, language or ethnicity, are discriminated and denied full privileges [1]. As was well put by Heater [8], there are different hierarchies of citizenship:

At the top of the ladder, there are the full and active citizens. These are individuals/groups who have the most complete set of rights and who most fully discharge their civic duties. On the second rung down, there are the full but passive citizens. These are citizens with full citizenship rights but being apathetic about performing duties. At the third level down, there are second-class citizens. These individuals have the legal status of citizenship, but because of discrimination and segregation, they are deprived from the full practices of citizenship rights. At the fourth level are under classes. Like the second-class citizens, these citizens have the legal citizenship status. However, since they are economically and culturally impoverished, they are in effect excluded from the normal style of social and political activity, which the term, citizenship, connotes [8. P. 87].

It is obvious that hierarchy of citizenship is undesirable and it has to be avoided at all costs [4]. As a result, increasing awareness about the diverse and pluralistic nature of modern societies in different parts of the world, including Ethiopia, has encouraged scholars to question and even reject the idea of 'universal' citizenship. In replacing it, multicultural citizenship is expected to be a viable alternative that can help to avoid exclusions and hierarchies [4]. This kind of citizenship calls for the recognition (alongside universal rights) of 'special rights': rights that are special in that they apply only to specific categories of people [4].

Attracted by its undeniable advantages, Ethiopian ethno-nationalists had been propagating multicultural citizenship, which eventually became a state policy when EPRDF came to power [9]. It is argued that the current political arrangement is democratic as it recognizes and practically ensures equal access of all nationalities to the basic citizenship entitlements ([2]; [10]). Critics, on the other hand, argue that in spite of the country's transition to multicultural citizenship, the legal and practical experiences of different regions show that the hierarchy of ethnicities continues, even to a higher degree, mainly at sub-state levels [11]. BGRS is one of such sub-state units, where Amharas ${ }^{2}$ and other non-titular nationalities are claimed to be deprived of basic citizenship rights, such as political representation in the parliament and the cabinet [11], with an explicit division of its inhabitants into 'owners' and 'non-owners' [12]). Therefore, the purpose of the current research is to critically examine the membership and self-governing status

${ }^{2}$ Amhara is the second largest ethnic group both in Ethiopia and BGRS [16], with its 'home' region of Amhara National Regional State. 
of Amhara in BGRS. Analyzing citizenship practices in BGRS, which designates almost half (43\%) of its population as 'non-owners', appears practical as it can shed light upon the flaws in the implementation of multicultural citizenship. We have selected Amharas' case because it is the region's largest ethnic group, which frequently claims exclusions and marginalization [11].

As has been mentioned above, there are different dimensions of citizenship that need to be addressed in order to get a full picture of the status. However, this paper selectively focuses on membership and self-governing status, as the other elements will be analyzed in subsequent articles. Specifically, the research is aimed at:

$\checkmark$ examining the region's politics of 'belonging' and its implication for the membership status of Amharas;

$\checkmark$ exploring de jure and de facto realities of the region in relation to Amha$r a$ 's self-governing status; and

$\checkmark$ analyzing how Amhara's self-governing and membership standing is related to the citizenship status of its residents.

In fact, there has been a significant amount of research that has investigated the political representation of Amhara [11], inter-ethnic conflicts between the highlanders and lowlanders in BGRS [11]), and the protection of ethnic minorities at the sub-state levels [12]. However, none of these studies analyzed Amhara from the perspective of how membership and self-governing are related to and important for the citizenship status of the new minorities. This specific angle of analysis is what makes the current investigation particularly relevant.

\section{Research Method}

The dominant method used in this paper is qualitative research. The author seeks to interpret and make sense of the experiences, opinions and views of the concerned actors about the implications of membership and self-governing for the citizenship status in Amhara. Qualitative research appeared to be logical for the stated purpose. Quantitative data that give an idea about the size and proportion of population support the qualitative method. Qualitative descriptions were used to back up the quantitative data. Therefore, it is possible to say that a concurrent embedded mixed approach ${ }^{3}$ was employed.

The data were collected by means of face-to-face semi-structured interviews and document analysis. The participants were chosen with the help intensity sampling method ${ }^{4}$ upon consent. The interviewees were selected from two categories: government officials (from federal to district levels), and 'ordinary' citizens.

\footnotetext{
${ }^{3}$ Concurrent embedded mixed approach is a study technique in which one method of research is dominant and another one is supportive [15].

${ }^{4}$ Intensity sampling procedure is a purposive sampling technique variety that selects examples according to their capacity to provide in-depth information and important knowledge about the phenomenon of interest [15].
} 
Among the government participants, we interviewed: one official from the House of Federation, four officials from BGRS offices, two individuals from Amhara National Regional State (ANRS), five officials from Pawe woreda ${ }^{5}$, four officials from Assosa woreda, and three officials from Bambasi woreda ${ }^{6}$.

The participants from the "ordinary" group were chosen from both the titular citizens and Amhara ethnic communities. The titular nationalities included two Berthas, two Gumuz and one Shinasha. Seven 'ordinary' Amharas were chosen among Amharas living in Assosa and Bambasi districts. Based on this, we conducted 29 interviews, the size of which was determined by the saturation of the data. The interviews were conducted in the period between January and February 2019 at various locations and took $45-120$ minutes.

In addition to the interviews, pertinent data were collected through consulting different secondary sources, such as the federal and regional constitutions, reports of Ethiopia's Central Statistical Agency (CSA) and published research reports. Among the extensively utilized resources were: the 1995 Federal Constitution of Ethiopia, the 2002 revised constitution of BGRS, the 2002 revised constitution of ANRS (for comparative purpose), and the 1994 and 2007 national census reports of Ethiopia's CSA. Finally, the data were examined with the use of qualitative thematic analysis, which was supported by the quantitative description.

\section{Results and Discussion}

\subsection{The Region's Politics of Recognition and Amharas' Membership Status}

The main legal document that addresses the politics of "belonging" to the region's political community is the 2002 revised regional constitution. The regional constitution, by which the local politics of recognition is enacted, identifies two types of inhabitants: 'owners' and 'non-owners'. It states the following: 'although other peoples will be recognized, the owners of BGRS are Mao, Komo, Shinasha, Gumuz, and Bertha [14. Art. 2]'. This constitutional framework creates two types of ethnic groups, one of which is granted the privilege of being legal members of the region, while the other is given a secondary status of inhabitants [12]. Thus, while some members of the local community are entitled to assert and defend their rights, others are denied this opportunity, as they do not enjoy an equal status of "belonging". In relation to this, interviewee 22 from the Amhara community stated: "We and the five nationalities do not have an equal legal status in this region. While they have the full ownership status, we are regarded as aliens living in the area at the mercy of the owners".

Despite the fact that Amharas and other non-titular nationalities are citizens of Ethiopia and account for almost half (43\%) of the region's population (see table 1), the politics of recognition employed by BGRS does not give such a significant number of inhabitants the ownership status. This situation creates hierarchy of ethnicities [11] and, as a result, an in-

\footnotetext{
${ }^{5}$ Woreda is an Amharic term meaning "district".

6 These three areas were selected because of the relatively high number of Amhara inhabitants living there [16].
} 
equitable citizenship status too. The division of inhabitants into 'owners' and 'non-owners' is not supported even by informants from the owner nationalities. Interviewee 12 from the Shinasha community commented: “... sure we shall not let our people face the historical assimilation. However, the terminology of the constitution referring to the five minorities as the 'owners' of the region is radical. That is why we, academicians, prefer to use the term 'indigenous' rather than 'owners”' (28 January 2019, Assosa).

Table 1

Ethnic makeup of BGRS

\begin{tabular}{|c|c|c|}
\hline \multicolumn{3}{|c|}{ Titular ethnic groups } \\
\hline Ethnic group & Population in Number & Proportion in \% \\
\hline Bertha & 199,303 & $25.4 \%$ \\
\hline Gumuz & 163,781 & $20.6 \%$ \\
\hline Shinasha & 60,587 & $7.7 \%$ \\
\hline Mao & 15,384 & $1.8 \%$ \\
\hline Komo & 7,773 & $0.99 \%$ \\
\hline Total & 447,028 & $\approx 57 \%$ \\
\hline Amhara & Non-titular ethnic groups \\
\hline Oromo & 170,132 & $21.7 \%$ \\
\hline Agaw-Awi & 106,275 & $13.4 \%$ \\
\hline Tigre & 33,061 & $4.2 \%$ \\
\hline Others & 5,562 & $0.7 \%$ \\
\hline Total & 22,287 & 2.8 \\
\hline
\end{tabular}

Source: Computed by the researcher with reliance on the 2007 national census report.

Apart from the 'undesirable' hierarchies, the division issue is criticized for violating the federal constitution. In regard to this, an official from ADP's Branch office in Assosa stated:

The issue of ownership of BGRS was politically decided in contrary to the federal constitution and history. Since the transition was led by TPLF, it was this group who made the five nationalities the owner of the region while Amhara with large population size and historical attachment to the area is excluded (January 18, 2019).

As is stated in article 46 (2) of the FDRE constitution [17], regional administrations and self-governing status are expected to be established with due consideration of language, ethnic identity, settlement pattern and peoples' willingness. If we use these criteria as a guide for self-governance, we cannot exclude the population size of the people living in that area. If this was the case, then how is it possible for Amharas that constitute $21.7 \%$ of the total population in BGRS, as compared to the Gumuz, Shinasha, Mao and Komo, making up 20.6 \%, $7.7 \%, 1.8$ $\%$ and $0.99 \%$ of the region's population respectively (See table 1), to be excluded? This fact seems to be paradoxical: while Komo with $0.9 \%$ are among the 'owning' members of the region, Amharas with $21.7 \%$ are deprived of such status. Beyond all doubt, the current situation is contrary to the stated article of the federal constitution.

Here, some may argue that such hierarchical politics of recognition emanates from the very nature of ethnic federalism that the country abides by. Never- 
theless, such supposition does not appear logical if one examines the experience of Amhara National Regional State (ANRS). The largest ethnic group among the nationalities that constitute ANRS is Amhara. It accounts for $94.4 \%$ of the region's population, and only $5.6 \%$ is represented by other nationalities [18]). However, the constitution of ANRS does not have an article that gives an exclusive ownership of the region to Amhara [12]. Instead, the constitution confers equal recognition for all nationalities living in the region. It may serve as an eloquent example that the BGRS constitution preamble [14] begins with "We, the people of Bertha, Gumuz, Shinasha, Mao and Komo...", while the ANRS constitution [19] preface reads: "We, the people of Amhara National Regional State..." Moreover, while the BGRS constitution [14: art.2] has an article that gives an exclusive ownership right to five nationalities, the 'owners' of ANRS are all nationalities living in the region [19. Art. 8]. If exclusiveness were embedded in the very nature of ethnic federalism, ANRS would have also a similar discriminative law. Hence, it seems that the issue is a matter of political willingness and commitment.

There exist other opinions stating that such exclusions result from the institutionalization of multicultural citizenship, which focuses on group identities [12]. However, such speculation does not appear to be reasonable as well: de jure and de facto realities of the region contradict the main tenets of the differentiated/multicultural citizenship concept. The main aim of multicultural citizenship is ensuring that minorities have the same political and socio-economic entitlements as other ethnicities (Kymlicka 1995), and not creating a 'majority minority' through hierarchical politics of recognition. In spite of the fact that the purpose of multicultural citizenship is to avoid exclusions and marginalization along cultural, linguistic or ethnic lines [14], the politics of recognition employed in BGRS demonstrates inequality, as certain ethnicities, despite being numerical majorities, such as Amharas, are designated to have a secondary status.

The regional constitution does not clearly state the criteria used to distinguish some residents as 'owners' and others as 'non-owners'. However, some regional officials associate it with temporal chronologies of living in the area (interviewee 17 from BGRS council office, February 13, 2019, Assosa). Nevertheless, the federal constitution does not mention history as a criterion for establishing an administrative or ownership status. Moreover, relying on 'historical presence' as a reference for granting ownership is highly problematic, as numerous nationalities did not have a permanent place of residence. An area inhibited by one ethnic group at a certain point in history was also inhibited by a different ethnicity at another point in time [11]. This argument challenges the idea that the length of historical presence on a certain territory should be considered a criterion for assigning the ownership status. Thus, temporal chronology cannot serve as a legal basis for granting privileges, as it can become another bone of contention among the multiple regional ethnicities.

The examples above demonstrate that the exclusionary politics of recognition employed in the region does not have any rational justification. Moreover, it is illegal, since it contradicts article 46(2) of the Federal Constitution. It also challenges the main principle of the multicultural citizenship notion: instead of ensuring inclusiveness and equal 
politics of recognition, BGRS implements multiculturalism in a manner where majorities are excluded from basic membership status. Thus, the provisions of the revised regional constitution create a citizenship hierarchy, in which Amharas and other non-titular nationalities are implicitly recognized as second-class citizens.

\subsection{Self-Governing Rights}

Both Kymlicka [4] and Young [5], pioneers of group based recognition, believe self-governance to be a tool protecting ethnic 'minorities' from marginalization and oppression. In particular, the self-governing right is a core element of the multiculturalists' notion of citizenship. For Kymlicka [4], recognition and institutionalization of the right for self-governance is a crucial institutional mechanism that must be used to address inequality. The federal government of Ethiopia attempts to ensure the rights for self-determination and self-government of the nations, nationalities and peoples of Ethiopia, which is unequivocally stated in article 39 of the Constitution [17]. In institutionalizing these rights, various regions, nationality zones and special woredas are created for the dominant ethnolinguistic groups.

BGRS has 'adapted' the federal constitution and recognized the selfdetermination rights of nationalities and people in the region. Nonetheless, the adapted version of the constitution grants the self-governance right exclusively to the "owners": article 39 is devoted to "the self-determination rights of owner nationalities" [14. Art. 39]. All the specific rights, listed in the articles, such as the right to self-governance, the right to maintain and develop one's culture, the right to equal representation in the regional and federal government structures, etc., are not applicable to Amharas and other non-titular nationalities in the region, no matter the size of their population (Interviewee 17 from $A D P$ office at Assosa, 16 February 2019, Assosa).

...while minority nationalities such as Komo and Mao are enjoying selfadministration rights, we, Amharas, are not even named by the constitution, let alone possess the self-administration right. If this is the reality, how can I consider myself a citizen of Ethiopia equal to a Mao and Komo? (Interviewee 01 from Amhara, February 16, 2019, Bambasi).

Though Amharas claim their right to exercise self-governance authority like the rest, there is stiff opposition from the side of the 'owners'. According to the 'owner' respondents, granting a self-administration right for a non-titular nationality is a violation of the regional constitution and the very idea of federalism. One of the titular informants indicates: "Since BGRS is created to empower minorities through self-determination, this empowerment shall not be challenged by allowing non-owners to determine over a certain administrative level to which they are not the owner" (interviewee 11 from Shinasha, 28 January 2019, Assosa). As various informants explained, the heavy opposition of the owner nationalities is caused by two reasons. The first reason is the exclusionary politics of recognition enshrined in the constitution. Since the constitution ordains that they are the 'owners' of the region and exclusive bearers of self-determination right, they claim this right to be 
solely theirs. The second reason has to do with their concern that their rights will be taken away from them and they may face the marginalization of the past, if the 'non-owners' are treated equally.

In spite of the fact that self-determination and administrative arrangements (regions, nationality zones, and special districts) are established with regard for the ethnic identity that has the largest number of inhabitants in the administrative area, the implementation is not consistent across different regions, and even within a single region, as is the case with BGRS. In relation to this, Asnake [7] wrote: "like the practice of the Soviet Union, the decision to give a certain level of administrative status to ethnic groups solely rests upon the 'vanguard' party, the EPRDF. As a result, there are some paradoxes, which are still difficult to explain". BGRS' higher officials, however, explained that to single out the most numerous group is practically infeasible due to the high level of mixing between the ethnicities. This is how an informant from BGRS Council office put it:

Despite the fact that Amharas are the second largest group in the region, there is no single district inhibited by Amharas alone. Instead, the population is comprised by different nationalities, which makes it difficult to establish a special woreda /zone for a single ethnic group. Because of this problem, we are even unable to institutionalize nationality administrations for the owner ethnicities. (Interviewee 16, January 18, 2019, Assosa).

Though the officials' explanation seems to be reasonable, critics reveal that it is not the actual problem. Instead, they explain the situation by the unwillingness of the BGRS authorities to [properly] implement the tenets of multicultural citizenship and the federal constitution ${ }^{7}$. Moreover, a different solution to a similar problem in Pawe and Assosa districts contradicts the officials' commentary.

Pawe is one of the 20 woredas of BGRS. Before the 1990s, Pawe was part of the former Gojam province [7]. Nevertheless, when TPLF/EPRDF restructured Ethiopia's internal administrative divisions, Pawe became part of the newly created BGRS [7]. The inclusion of Pawe into BGRS was, however, controversial. The residents of this district, including its higher officials, claim that they would reside in ANRS if the demarcation was based on the criteria of the federal constitution.

If the historical linkage and people's consent were considered, we would not be part of BGRS. If culture, language, mentality, geographical proximity, and ethnic identity were considered, we would belong to ANRS rather than BGRS. (Interviewee 05 from Pawe woreda administrative office, January 10, 2019, Almu)

On the other hand, the titular interviewees justify the territorial division based on historical possession the same way the officials rationalize the ownership entitlement. 'Despite the fact that Pawe is now inhibited by the settlers, the land had been occupied by the indigenous people before the arrival of the settlers in the 1970s and 1980s. Making it part of BGRS is justified from this perspective' (interviewee 13 from Gumuz ethnic group, January 19, 2019, Gilgel Beles). Nev-

${ }^{7}$ Walta TV, an interview with Yaregal Aysheshm, former president of BGRS. Available from: https://www.youtube.com/watch?v=w9J6XFWEd_E. Accessed: 10.10.2019. 
ertheless, as has been mentioned before, history is not considered a criterion for delimiting the internal borders. The guidelines for internal border demarcation are ethnic identity, willingness of the people, language, and settlement pattern [17: art.46]. None of these criteria, however, allowed the inclusion of Pawe into BGRS, as the vast majority (80\%) of its inhabitants are Amharas (see table 2). The proportion of the titular nationalities in this district is negligible: combined, they constitute only $0.43 \%$ of the district's population. It seems paradoxical that $0.43 \%$ of the population 'own' the district, while the remaining $99.57 \%$ (see Table

2) are denied the legal status of ownership [14].

Table 2

Ethnic makeup of Pawe Woreda

\begin{tabular}{|c|c|c|}
\hline Ethnic group & Population size & Percent \\
\hline Amhara & 36,309 & $79.72 \%$ \\
\hline Kambata & 2,111 & $4.63 \%$ \\
\hline Haddiya & 2,050 & $4.51 \%$ \\
\hline Oromo & 1,009 & $2.21 \%$ \\
\hline Somali & 875 & $1.92 \%$ \\
\hline Tigre & 374 & $0.82 \%$ \\
\hline Titular nationalities & 198 & $0.43 \%$ \\
\hline others & 2,626 & $5.76 \%$ \\
\hline Total & 45,552 & $100 \%$ \\
\hline
\end{tabular}

Source: Computed by the researcher with reliance on the 2007 national census report.

In terms of the settlement pattern, Pawe is territorially adjacent to the Amhara region. "The intense opposition of the people against being incorporated into BGRS is also undeniable" (interviewee 27 from Pawe Woreda Administrative and Security Office, January 22, 2019, Almu). All the contradictions considered, what could the rationale behind the inclusion of Pawe into BGRS? In reply to this question, an informant from ANRS President Office commented: "nothing, except political supremacy of the group that led the transition" (January 4, 2019, Bahirdar).

Apart from the illegitimate incorporation, the denial of the self-governing status to the Amharas in Pawe is another reason for them to feel discriminated, marginalized and oppressed. Although the inhabitants of Pawe have had a special woreda status since 1994 [7], they lost this status by the decision of the regional council in 2012 (interviewee 07 from ADP's branch office at Pawe, January 12, 2019, Almu).

Enjoying a self-governing status is regarded as a central entitlement in multicultural citizenship [4]. However, the practice of BGRS prohibits Amharas from enjoying this right and is therefore found to be discriminatory. It also violates the constitutional proclamation, which declares that 'every Nation, Nationality and People in Ethiopia has the right to a full measure of self-government, which includes the right to establish institutions of government in the territory that it inhabits and to equitable representation in state and federal governments' (FDRE 
constitution, 1995, art. 39(3)). "If this article was genuinely implemented, there would be a special administrative structure (woreda) for the Amharas of Pawe, as they make up the majority of the district's population." (interviewee 08 from ADP's central office, January 7, 2019, Bahirdar). More specifically, compared to the case of Mao-Komo, who have a woreda of their own while covering $40.88 \%$ of the community (CSA, 2007), the prohibition of Amharas in Pawe, accounting for $80 \%$ of the district's population, is illegitimate.

There is also a justifiable claim for Amharas to be able to exercise selfgoverning rights in Assosa woreda. Assosa woreda is part of Bertha dominated Assosa zone. Assosa woreda is inhibited by Amharas (55.4\%), Berthas (33.2\%), Oromos $(9.5 \%)$ and other nationalities (2.9\%) [16]. "The majority of the residents of this district are Amharas... however, the administration and ownership of this district is the hands of Berthas" (interviewee 14 from Amhara, February 8, 2019, Assosa). Because of this, the Amharas of Assosa woreda have been demanding a special woreda status. "Following the banning of Amhara candidates from candidacy of the 2000 election, we raised a question about arranging a special woreda of our own, however, our demand was declined by the state council" (interviewee 07 from Amhara, January 16, 2019, Assosa). This situation, once again, clearly demonstrates the discrimination against the Amhara ethnicity.

It is noteworthy, that there exists an alternative way to allow Amharas to implement the self-administration right. "From the 74 Kebeles of Assosa Woreda, 38 are exclusively inhabited by Amharas and 36 are populated by Berthas and Oromos (interviewee 15 from ADP's branch office in Assosa, January 19, 2019, Assosa)". Moreover, Assosa woreda is one of the most populated in the region $(104,147)$, as compared to Kurmuk $(16,734)$, Yaso $(12,747)$, Sirba Abay $(17,966)$, Kamashi $(17,883)$, and Guba $(14,907)$ [16]. Provided there is enough political will and commitment, Assosa woreda could be divided into two administrative units (one for Amharas and one for Berthas), thus ensuring Amharas' self-governing rights. The redistricting can be implemented easily, since the settlement pattern is conducive and the population size of Amhara $(57,281)$ is more than sufficient to administer a separate woreda.

To sum up, while there are sufficient legal (the FDRE constitution, at the very least) and practical grounds for Amharas to be able to exercise selfgoverning rights and be granted their own woreda, Amharas are deprived of this right. This is contradictory to the federal constitution, idea of federalism and tenets of multicultural citizenship. Regional constitutions are the source of marginalization and discrimination, as they grant self-determination and self-governing rights only to the titular nationalities. As a result, despite the fact that the Amharas of BGRS are 'citizens of Ethiopia' by law, they are not treated equally to the titular nationalities and are relegated to the secondary citizenship status in the region.

\section{Conclusion}

The aim of the paper was to examine the membership and self-governing authority of Amharas in BGRS and analyze its effect on the citizenship status at 
the sub-state levels. The main document that determines the inclusion/exclusion of nationalities in the region is the 2002 revised constitution of BGRS. This constitution is found to be exclusionary towards certain ethnicities, as it gives ownership entitlements to five nationalities of the region and excludes a major portion of the population. Though Amharas are the second largest community in the area, the regional constitution rules them out from the basic socio-political entitlements.

In addition to being 'blackballed' from being part of member community, Amharas of BGRS are denied their self-governance right. Self-governing prerogative is a fundamental right in the multiculturalists' notion of citizenship. Nonetheless, as was in the case with establishing the territorial 'ownership', the regional constitution ordained an exclusionary distribution of the self-governing right. Article 39 of the regional constitution declares that the owner nationalities are exclusively entitled to enjoy self-determination rights. Although there are legal (the FDRE constitution) and practical grounds (mainly the Pawe and Assosa cases) for Amharas to exercise self-governing rights and obtain a woreda of their own, they are banned from doing so. This situation arose mainly due to lack of political will and commitment. Besides the de jure exclusions, practical violation of Amhara's citizenship rights in the region also takes place. In general, although Amharas of BGRS are 'citizens of Ethiopia' by law, they are excluded from the underlying citizenship entitlements. The exclusionary politics of recognition and preventing Amharas from exercising self-government rights, both by law and practice, attest to a hierarchical citizenship practice in the region, in which Amharas are treated as second-class citizens.

\section{ADDITIONAL INFORMATION}

Acknowledgments: This research is a contribution to the Mega Research, which received financial assistance from University of Gondar. Hence, the author extends his heartfelt gratitude to University of Gondar for funding the project. The author also thanks Mr. Daniel Belay and Mr. Yibeltal Degwale for their useful comments, particularly on the language of the paper.

\section{REFERENCES}

[1] Heywood A. Political Theory: An Introduction. $3^{\text {rd }}$ ed. Palgrave Macmillan publisher; 2004.

[2] Stokke K. Conceptualizing the Politics of Citizenship. PCD Journal. 2013.

[3] Banks J. Diversity, Group Identity, and Citizenship Education in a Global Age. Educational Researcher. 2008; 37 (3): 129-139.

[4] Kymlicka W. Multicultural Citizenship. Oxford: Oxford University Press; 1995.

[5] Young M. Polity and Group Difference: A Critique of the Ideal of Universal Citizenship. Ethics. 1989; 99 (2): 250-274.

[6] Mass W. Multilevel Citizenship. The Oxford Handbook of Citizenship. Shachar A., Bauböck R., Bloemraad I., Vink M (eds.). Oxford: Oxford University Press; 2017: 644-668.

[7] Asnake K. Federalism and Ethnic Conflict in Ethiopia: A Comparative Study of the Somali and Benshangul-Gumuz Regions. Leiden University publisher; 2009.

[8] Heater D. What is Citizenship? Cambridge: Cambridge University Press; 2009. 
[9] Birhane G. Citizenship in Ethiopia: From Exclusion to Differential Treatment. Journal of Citizenship and Morality. 2017; 1 (1): 50-77.

[10] Assefa F. Federalism and the Accommodation of Diversity: A Comparative Study. Netherlands: Wolf Legal Publisher; 2006.

[11] Abbink J. Ethnic-based Federalism and Ethnicity in Ethiopia: Reassessing the Experiment after 20 Years. Journal of Eastern African Studies. 2012; 5 (4): 596-618.

[12] Vander Beke C. Ethiopia: Constitutional Protection of Ethnic Minorities at the Regional Level. Afrika Focus. 2007; 20 (1): 105-151.

[13] Marshall T.H. Citizenship and Social Class and Other Essays. Cambridge: University of Cambridge Press; 1950.

[14] Benshangul-Gumuz Regional State Council. The Revised Constitution of BenshangulGumuz Regional State. Assosa; 2002.

[15] Creswell J. Research Designs: Qualitative, Quantitative and Mixed Methods. 3rd ed. Sage publishing; 2009.

[16] Central Statistical Agency (CSA) - Ethiopia. Ethiopian 2007 Census Report. Addis Ababa; 2007. Available from: http://www.csa.gov.et/census-report/completereport/census-2007. Accessed: 11.10.2019.

[17] Federal Democratic Republic of Ethiopia. Constitution of the FDRE. Addis Ababa: Mega Printing Press; 1995.

[18] Central Statistical Agency (CSA) - Ethiopia. Ethiopian 1994 Census Report. Addis Ababa; 1994. Available fromt: http://www.csa.gov.et/census-report/completereport/census-1994. Accessed: 11.10.2019.

[19] Amhara National Regional State Council. The Revised Constitution of Amhara National Regional State. Bahirdar; 2002.

Научная статья

\title{
Мультикультурное гражданство и статус "других» в Эфиопии после 1991 г.: \\ анализ идентичности и самоуправления народа Амхара в региональном штате Бенишангул-Гумуз
}

\author{
К.Т. Мулуйе \\ Университет Гондэр \\ 196, Гондэр, Эфиопия
}

\begin{abstract}
Аннотация. После смены политического режима в 1991 году правительство Эфиопии стремилось институционализировать инклюзивное мультикультурное гражданство в стране. Статус национальной принадлежности и права на самоуправление являются важнейшими правами в концепции гражданства сторонников мультикультурализма. Несмотря на то, что гражданство относится к сфере внутренних дел государства, оно также зависит от политики субгосударственных политических единиц. Таким образом, в данной статье рассматриваются проблемы принадлежности и статус самоуправления амхарского народа и анализируется влияние статуса гражданства на субгосударственные единицы с акцентом на региональный штат Бенишангул-Гумуз. Параллельно автор опирался на анализ данных, собранных при помощи интервью и анализа документов. Данные интервью были получены от 29 респондентов, отобранных методом интенсивной выборки. Количественные данные были также получены от Центрального
\end{abstract}


статистического управления Эфиопии. Собранные данные были проанализированы посредством качественного и количественного анализа. Несмотря на то, что амхарцы из Бенишангул-Гумуз имеют правовой статус граждан Эфиопии, региональному штату не удалось полностью интегрировать этих людей. В частности, исключительная политика национального признания (поскольку только избранные национальности получают так называемую «собственность региона») и запрет народу Амхара на осуществление прав самоуправления (это право предоставляется исключительно национальностям«собственникам» региональной конституцией) демонстрируют иерархию гражданства, где народу Амхара в штате Бенишангул-Гумуз рассматриваются как «граждане второго сорта», что противоречит самому понятию мультикультурного гражданства.

Ключевые слова: Амхара, этнический федерализм, Эфиопия, мультикультурализм, мультикультурное гражданство, политика идентичности

\section{Информация об авторе:}

Китемо Тируне Мулуйе - преподаватель кафедры гражданских и этических исследований Университета Гондэр (Эфиопия) (ORCID ID: 0000-0001-6104-8807) (e-mail: ketemaw.muluye@uog.edu.et).

\section{Information about the author:}

Ketemaw Tiruneh Muluye - Lecturer of the Department of Civic and Ethical Studies, University of Gondar (Ethiopia) (ORCID ID: 0000-0001-6104-8807) (e-mail: ketemaw.muluye@uog.edu.et).

\section{Для цитирования:}

Muluye K.T. Multicultural Citizenship and the Status of 'Others' in the Post 1991 Ethiopia: A Study on Membership and Self-Governing Status of Amhara People in BenishangulGumuz Regional State // Вестник Российского университета дружбы народов. Серия: Государственное и муниципальное управление. 2019. Т. 6. № 4. С. 332-345. DOI: 10.22363/2312-8313-2019-6-4-332-345

\section{For citation:}

Muluye K.T. Multicultural Citizenship and the Status of 'Others' in the Post 1991 Ethiopia: A Study on Membership and Self-Governing Status of Amhara People in Benishangul-Gumuz Regional State. RUDN Journal of Public Administration. 2019; 6 (4): 332-345. DOI: 10.22363/2312-8313-2019-6-4-332-345 